Contributions:

A Study design/planning

B Data collection/entry

C Data analysis/statistics

D Data interpretation

D Preparation of manuscript

E Preparation of manuscript

$\mathrm{G}$ Funds collection

\title{
SOME REASONS FOR THE FAILURE OF SURGICAL TREATMENT OF OTOSCLEROSIS: LESSONS FROM A CASE STUDY
}

\author{
Henryk Skarzynski ${ }^{1,2 \mathrm{AE}}$, Lukasz Plichta ${ }^{1 \mathrm{FE}}$, Beata Dziendziel ${ }^{2 \mathrm{BE}}$, \\ Monika Boruta ${ }^{1,2 B D E}$, Piotr H. Skarzynski ${ }^{2,3,4 A E F}$
}

\author{
${ }^{1}$ Institute of Physiology and Pathology of Hearing, World Hearing Center, Oto-Rhino- \\ Laryngology Surgery Clinic, Warsaw/Kajetany \\ ${ }^{2}$ Institute of Physiology and Pathology of Hearing, World Hearing Center, Warsaw/Kajetany \\ ${ }^{3}$ Institute of Sensory Organs, Kajetany \\ ${ }^{4}$ Medical University of Warsaw, II Medical Department, Department of Heart Failure and \\ Cardiac Rehabilitation, Warsaw
}

\begin{abstract}
Introduction: Surgical treatment of otosclerosis requires considerable experience of the otosurgeon, especially in advanced cases or in an ear with an unusually narrow external auditory canal, a narrow niche of the round window, a significantly thickened stapes footplate, or an exposed or hanging facial nerve. Case involving subsequent reoperations by different surgeons can be particularly difficult. Collective knowledge of treatment failures during otosclerosis reoperation, as set out in the literature, does not list the difficulties encountered, fails to assess most causes of failure, and does not describe remedies and corrective techniques.

Material and methods: The course of treatment followed by a 55-year-old complaining of progressive, bilateral, mixed hearing loss due to otosclerosis is described. The patient's treatment consisted of stapes mobilization, followed by stapedotomy and restapedotomy of the right ear, and stapetodomy of the left ear.

Results: There was short-term improvement of hearing after mobilization of the stapes, but its subsequent deterioration, with elevation of both the air- and bone-conduction thresholds in the right ear, were indications for reoperation and stapedotomy. Short-term improvement in hearing was achieved after the operation, followed by rapid hearing loss. Due to this and growing balance disorders after nearly a year, a restapedotomy was performed with complete closure of the air-bone gap. Then, due to hearing deterioration in the left ear, a successful stapedotomy was performed in this ear.
\end{abstract}

Conclusion: Revision operations in otosclerosis require a lot of experience of the otosurgeon due to the many reasons for failure, particularly when the first surgery was performed elsewhere. An air-bone gap, severe tinnitus, and balance disorders are indications for reoperation by an experienced otosurgeon, as common causes of failure are postoperative adhesions and subsequent stapes immobilization.

Key words: otosclerosis, tinnitus, balance disorders, stapedotomy, reoperation, hearing loss

\section{ALGUNAS DE LAS CAUSAS DE LOS FRACASOS EN EL TRATAMIENTO QUIRÚRGICO DE LA OTOESCLEROSIS EN BASE A UN ESTUDIO DE CASO}

\section{Resumen}

Introducción: El tratamiento quirúrgico de la otoesclerosis, sobre todo avanzada o en un oído con el conducto auditivo externo atípicamente estrecho, nicho estrecho de la ventana redonda, engrosamiento significante de la platina del estribo o bien nervio facial expuesto y colgante requiere una considerable experiencia del otocirujano. Esto tiene particular importancia en casos en los cuales las consecutivas cirugías de revisión se realizan por diferentes cirujanos. El análisis conjunto, basándose en las fuentes bibliográficas, de los distintos casos de manejo de los fracasos durante las cirugías de revisión en la otoesclerosis a veces no refleja los obstáculos encontrados, no permite identificar la mayoría de las causas del fracaso y no indica soluciones eficaces y técnicas de reparación.

Materiales y métodos: Se analizó el curso del tratamiento de una paciente de 55 años con hipoacusia progresiva bilateral mixta en el desarrollo de la otoesclerosis. En la paciente se realizó la movilización del estribo, seguida de la estapedotomía y estapedotomía de revisión de oído derecho y la estapedotomía de oído izquierdo.

Resultados: Una mejora de la audición ligera y a corto plazo tras la movilización del estribo seguida de su deterioro con elevación de los umbrales tanto de conducción aérea como de conducción ósea en el oído derecho eran las indicaciones para realizar una cirugía de revisión y la estapedotomía. Tras la cirugía, se obtuvo una mejora de la audición de corta duración, seguida de un rápido deterioro de la audición. Por esta razón y por los trastornos del equilibrio progresivos, casi un año después se realizó una estapedotomía de revisión, cerrando por completo la reserva coclear. A continuación, debido al deterioro de la audición en el oído izquierdo, se llevó a cabo exitosamente la estapedotomía en este oído.

Conclusiones: Las cirugías de revisión en la otoesclerosis requieren gran experiencia del otocirujano, debido a la diversidad de las causas del fracaso, especialmente si las primeras cirugías se realizaron en un centro distinto. La identificación de la reserva coclear, tinnitus y trastornos del equilibrio progresivos son indicaciones para realizar una cirugía de revisión, la cual debería ser practicada por el otocirujano más experimentado, ya que la causas más comunes de los fracasos son atresias posoperatorias y la sucesiva inmovilización del estribo.

Palabras clave: otoesclerosis, tinnitus, trastornos del equilibrio, estapedotomía, cirugías de revisión, hipoacusia. 


\title{
НЕКОТОРЫЕ ПРИЧИНЫ НЕУДАЧ ПРИ ХИРУРГИЧЕСКОМ ЛЕЧЕНИИ ОТОСКЛЕРОЗА НА ОСНОВАНИИ ОПИСАНИЯ СЛУЧАЯ
}

\begin{abstract}
Резюме
Введение: Хирургическое лечение отосклероза, особенно в глубокой стадии или в ухе с нетипично узким наружным слуховым проходом, узкой нишей круглого окна, значительно утолщённой пластинкой стремени или открытым, нависающим лицевым нервом, требует очень большого опыта отохирурга. Это имеет значение в случаях последующих реопераций, проводящихся разными хирургами. Совокупный анализ на основании литературы предмета, разных случаев лечения неудач по время реопераций при отосклерозе часто не отражает встречающихся сложностей, не позволяет оценить большинства причин неудач и не показывает эффективных методов и техник по исправлению.
\end{abstract}

Материал и методы: Анализу был подвергнут процесс лечения 55-летней пациентки, связанного с прогрессирующей двусторонней смешанной тугоухостью по причине отосклероза. У пациентки была проведена мобилизация стремени, затем стапедотомия и повторная стапедотомия правого уха, а также стапедотомия левого уха.

Результаты: Краткосрочное незначительное улучшение слуха после мобилизации стремени, а затем его ухудшение с повышением пороговой кривой как для воздушной проводимости, так и для костной в правом ухе были показанием для проведения реоперации и выполнения стапедотомии. После операции было достигнуто краткосрочное улучшение слуха, но потом произошло его быстрое ухудшение. По этой причине, а также по причине растущих нарушений равновесия спустя почти год была проведена повторная стапедотомия с полным закрытием резерва улитки, затем по причине ухудшения слуха в левом ухе была успешно проведена также стапедотомия.

Выводы: Ревизионные операции при отосклерозе требуют большого опыта отохирурга в связи с разнородностью причин неудач, особенно если первые операции были проведены в другом учреждении. Обнаружение резерва улитки, нарастающих шумов и нарушений равновесия является показанием для проведения реоперации самым опытным отохирургом, поскольку наиболее частой причиной неудач являются заращения после операций и обездвиживание протезика.

Ключевые слова: отосклероз, шум в ушах, нарушения равновесия, стапедотомия, реоперации, тугоухость.

\section{NIEKTÓRE PRZYCZYNY NIEPOWODZEŃ CHIRURGICZNEGO LECZENIA OTOSKLEROZY NA PODSTAWIE OPISU PRZYPADKU}

\section{Streszczenie}

Wstęp: Leczenie operacyjne otosklerozy, zwłaszcza zaawansowanej lub w uchu z nietypowo wąskim przewodem słuchowym zewnętrznym, wąską niszą okienka okrąłłego, znacznie pogrubiałą płytką strzemiączka czy odsłoniętym, nawisającym nerwem twarzowym, wymaga znacznego doświadczenia otochirurga. Szczególnie ma to znaczenie w przypadkach kolejnych reoperacji wykonanych przez różnych chirurgów. Analiza zbiorcza, na podstawie literatury przedmiotu, różnych przypadków leczenia niepowodzeń podczas reoperacji w otosklerozie często nie odzwierciedla napotykanych trudności, nie pozwala ocenić większości przyczyn niepowodzenia oraz nie pokazuje skutecznych sposobów i technik naprawczych.

Materiał i metody: Analizie poddano przebieg leczenia 55-letniej pacjentki z powodu postępującego, obustronnego, mieszanego niedosłuchu w przebiegu otosklerozy. U pacjentki wykonano mobilizację strzemiączka, następnie stapedotomię i restapedotomię ucha prawego oraz stapedotomię ucha lewego.

Wyniki: Krótkotrwała niewielka poprawa słuchu po mobilizacji strzemiączka, a następnie jego pogorszenie z podwyższeniem zarówno krzywej progowej dla przewodnictwa powietrznego, jak i kostnego w uchu prawym były wskazaniem do reoperacji i wykonania stapedotomii. Po operacji uzyskano krótkotrwałą poprawę słyszenia, a następnie szybkie pogarszanie słuchu. Z tego powodu oraz narastających zaburzeń równowagi po prawie roku została wykonana restapedotomia z pełnym zamknięciem rezerwy słuchowej. Następnie z powodu pogarszającego się słuchu w uchu lewym wykonano z pełnym powodzeniem stapedotomię w tym uchu.

Wnioski: Operacje rewizyjne w otosklerozie wymagają dużego doświadczenia otochirurga ze względu na różnorodność przyczyn niepowodzenia, szczególnie, gdy pierwsze operacje zostały wykonane w innym ośrodku. Stwierdzenie rezerwy słuchowej, narastających szumów oraz zaburzeń równowagi jest wskazaniem do przeprowadzenia reoperacji przez najbardziej doświadczonego otochirurga, gdyż najczęstszą przyczyną niepowodzeń są zmiany zarostowe po kolejnych operacjach i unieruchomienie protezki.

Słowa klucze: otoskleroza, szumy uszne, zaburzenia równowagi, stapedotomia, reoperacje, niedosłuch

\section{Introduction}

Results of revision operations in otosclerosis are less satisfactory in comparison with those achieved after primary operations [1]. Postoperative hearing improvement depends on the surgical technique applied during the first operation(s), the reasons for failure, and the corrective procedure applied. The most common reasons for failure of post-primary stapedotomy include: destruction of the long process of incus, incus prognathism, dislocation of the prosthesis beyond the oval window, insertion of a too long or too short prosthesis, and the presence of a thickened footplate. Other reasons, such as a cochlear fistula, are rare. It is recommended that a revision be immediately carried out after stapedotomy when there is rapid deterioration of hearing after surgery or dizziness occurs. The progressive destruction of the long process of the incus and obliteration of the oval window will worsen the results of the treatment. However, if a cochlear fistula is present, it can lead to irreversible profound sensorineural 
A

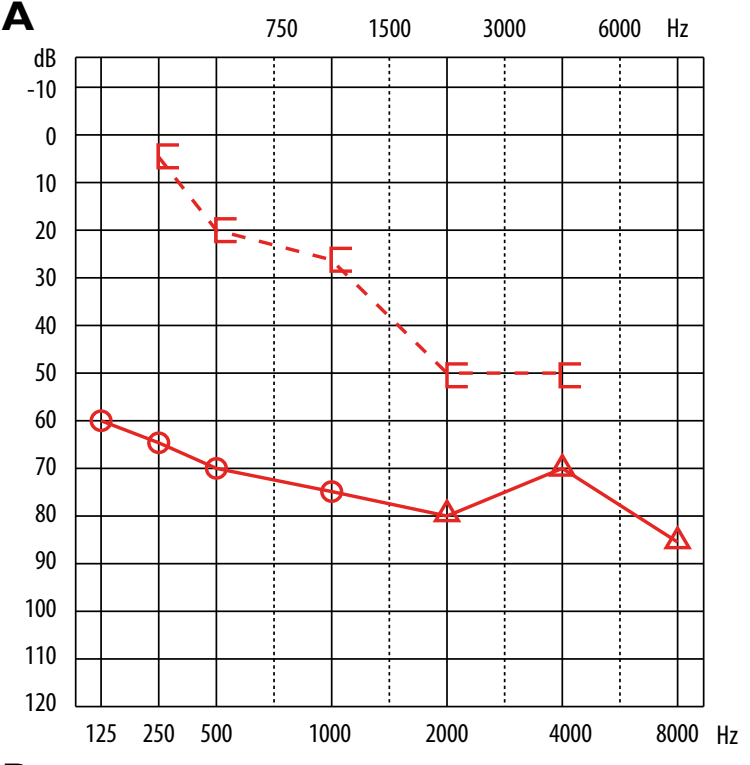

B $\quad 750 \quad 1500 \quad 3000 \quad 6000 \quad \mathrm{~Hz}$
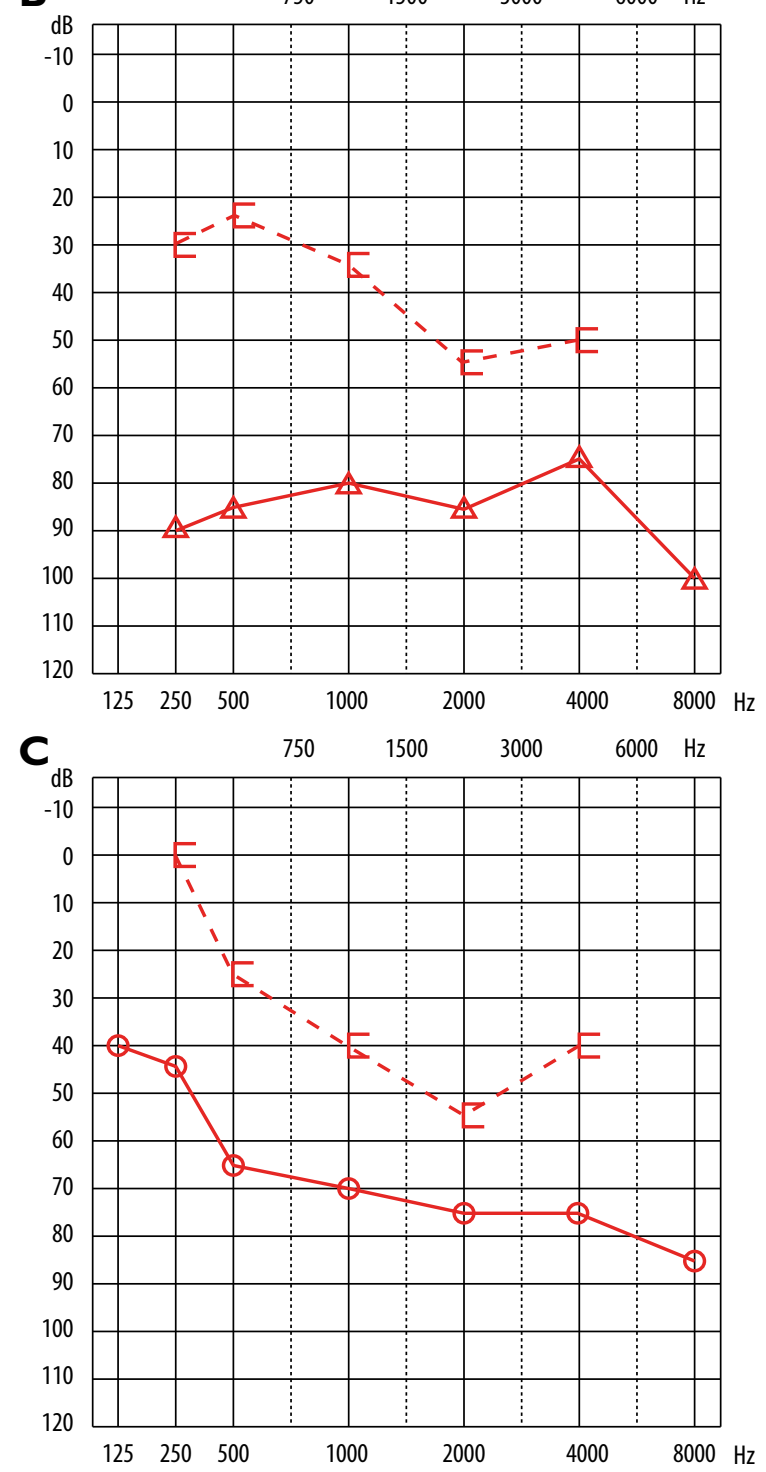
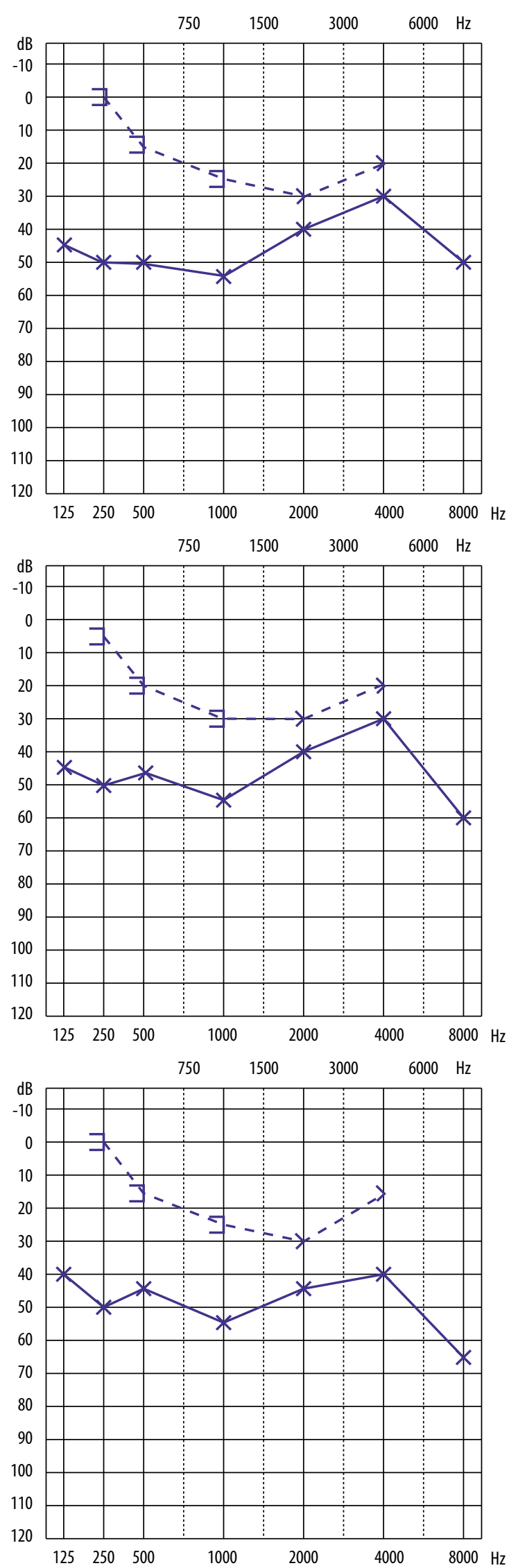

Figure 1. Result of audiometric test before mobilization (A), after mobilization (B), and after stapedotomy in the right ear (C)

(C) Journal of Hearing Science ${ }^{\circledR} \cdot 2018$ Vol. $8 \cdot$ No. 1 
hearing loss [1-5]. The collective knowledge of treatment failures during otosclerosis reoperation, based on the literature, does not describe the difficulties encountered, fails to assess most of the causes of failure, and does not list remedies. The example given in this paper provides a description of specific methods that can be applied and of otosurgical nuances.

\section{Material and methods}

\section{Case description}

The case pertains to surgical treatment of progressive, bilateral, mixed type hearing loss over 30 years in a 55 year old patient. Initially it developed only in the right ear, but then also spread to the left. A significant increase in hearing loss was observed by the patient after the birth of their fourth child. Tinnitus in the right ear then changed from intermittent to permanent. An attempt was made to fit a hearing aid, but due to poor tolerance, classic devices to improve air conduction hearing were abandoned, and an attempt was made to improve hearing surgically.

\section{Results}

During the first operation, exploratory tympanotomy in the right ear was performed along with mobilization of the stapes. The hearing improvement was not significant and according to the patient did not last longer than a week. For this reason, after 3 months she had a rightsided stapedotomy performed by another surgeon. After the surgery the patient's hearing improved slightly. After about 2 months, she began to notice periodic balance disorders. A few days before the patient was admitted to the Oto-Rhino-Laryngology Surgery Clinic of IPPH, there was intense dizziness and vertigo. Tinnitus in the operated ear also increased. The patient was therefore admitted urgently for reoperation of the right ear. Based on pure tone audiometry, a significant mixed hearing loss (on the BIAP scale) in the right ear and moderate hearing loss in the left ear were confirmed [6]. The air-bone gap calculated for $0.5,1,2$, and $4 \mathrm{kHz}$ was 31 $\mathrm{dB}$ in the right ear and $24 \mathrm{~dB}$ in the left (Fig. 1). Video-otoscopy showed that the tympanic membranes were preserved bilaterally, there was dilatation of the posterior and superior walls of the external auditory canal in the right ear, and there was a very narrow external auditory canal in the left.

The patient was scheduled for reoperation of the right ear. During exploratory tympanotomy performed by the third otosurgeon (H. Skarżyński), a significant postoperative dilatation of the auditory canal and a solid accretion mass in the region of the long process of incus and near both window niches were found. Upon removal of the accretion, the promontory, the round window membrane, and the footplate were revealed. No fistula was present. A large fragment of the anterior crus of the stapes was found, accreted against the prosthesis and promontory, which probably caused the persistent hearing loss and balance disorders. After its removal, a clear view of the entire region of the oval window was gained. The Teflon piston prosthesis (Mikołów type) was removed and a titanium Kurz Skarzynski prosthesis placed in its stead (Figure 2).

\section{Heinz Kurz GmbH Medizintechnik}

Skarzynski Piston
Titanium

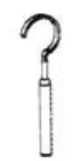

Figure 2. Kurz Skarzynski prosthesis with a diameter of $0.4 \mathrm{~mm}$, length $4.5 \mathrm{~mm}$

Full mobility of the middle ear conductive apparatus was obtained. To seal the orifice in the footplate, the piston was surrounded by a fragment of venous blood clot. The tympanic cavity was rinsed with Dexaven solution, and then a dermal-tympanic flap was fixed with tissue adhesive, and pressed with intraductal dressing to the bone at the dilatation of the canal (to prevent re-bleeding and formation of a retraction pocket). The dressing was removed from the canal after 7 days. Immediately after the operation, the patient reported absence of balance disorders and a reduction in tinnitus in the right ear. After 6 months, and after one year, the air-bone gap remained closed and there was a slight reduction in the bone conduction threshold. Because of deterioration in hearing and intensification of tinnitus in the left ear, a standard left ear stapedotomy was performed, resulting in closure of the air-bone gap and a significant reduction of tinnitus in that ear (Figure 3).

\section{Discussion}

Treatment of otosclerosis by stapedotomy or stapedectomy is commonly applied in adults. Although stapes surgery allows for effective improvement of hearing in the majority of patients, hearing loss can recur, requiring a revision operation to be carried out [7]. The number of failures of surgical treatment for otosclerosis is not well known. Bakhos et al. [8] report revision after stapes surgery in $10 \%$ of operated patients. The authors note this number may be higher because some revision operations are carried out elsewhere.

Revision after stapedotomy is a much more demanding procedure than the original $[3,9]$. The surgeon's experience may be decisive for postoperative hearing improvement, elimination of balance disorders, and full or significant reduction of tinnitus. Frequently it is only after exploratory tympanotomy that one can determine why previous surgeries failed and how hearing can be improved without taking an unreasonable risk.

The technique of stapes mobilization was first used by Rosen in 1953 [10]. However, it is rarely possible to reduce the air-bone gap to $10 \mathrm{~dB} \mathrm{HL}$, and in the longer term an increase in the air-bone gap is quite common. At a 3-year follow-up, hearing improvement is maintained in only 60 of 100 patients. Therefore, taking into account the natural course of the disease, this technique should not be routinely used in the treatment of otosclerosis.

In the discussed case, mobilization of the stapes during the first procedure improved the patient's hearing (for a few days), and also contributed to an increase in the 
A

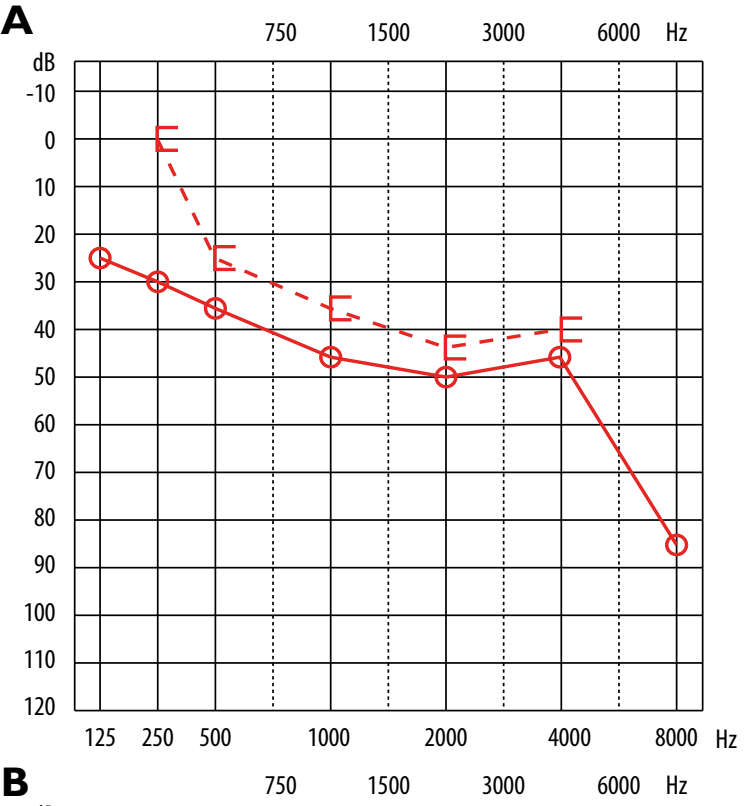

B

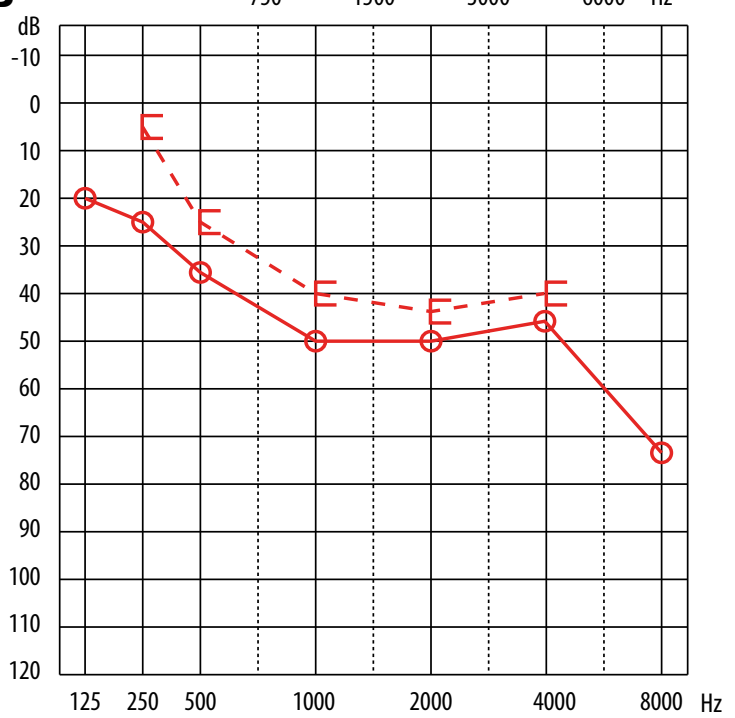

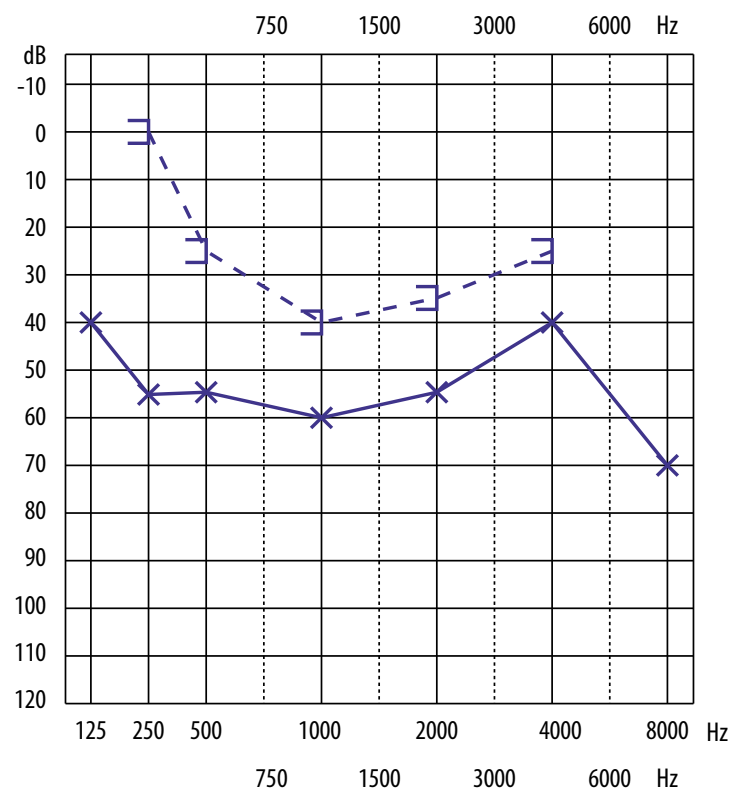

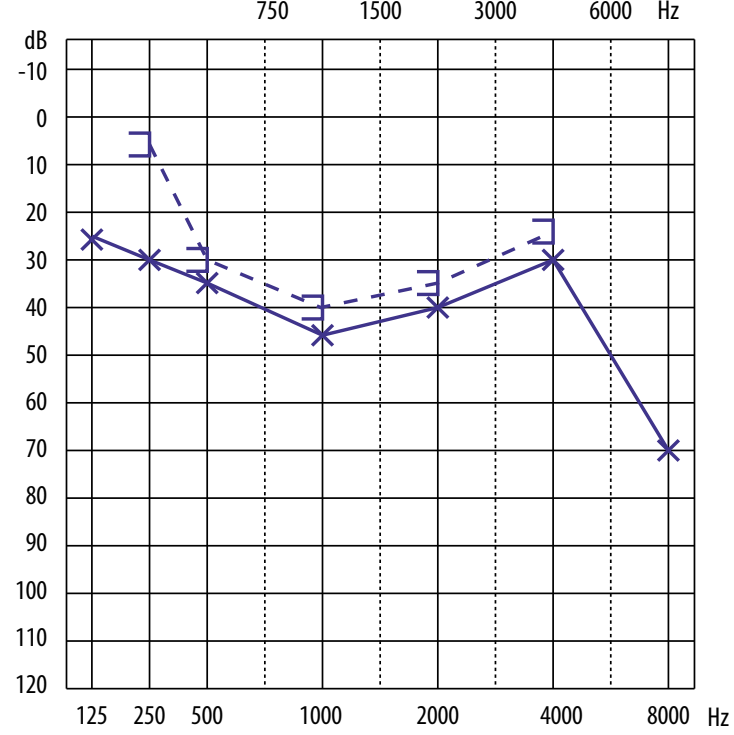

Figure 3. Result of audiometry after 1 and 12 months following re-stapedotomiy in the right ear (A) and 6 months after stapedotomy in the left ear (B). Right ear in red; left ear in blue

bone conduction threshold. The narrow external auditory canal presented a difficulty, which forced both the first and second otosurgeon to significantly widen it. As a result, this may have caused the skin of the external auditory canal to overlap the process of the incus and induce accretions. Accretion lesions can also result from ineffective pressing of the dermal-tympanic flap to the bony canal wall. This probably also contributed to increased post-operative bleeding into the tympanic cavity and caused a large solid accretion to form. It is believed that the use of dressing in the external auditory canal, laid on foil, provides a good hemostatic effect and helps the dermal-tympanic flap to heal in the correct position [11]. Nevertheless, even though stapedotomy is a common procedure, the literature does not give a clear indication of whether the use of a dressing to the external auditory canal after the surgery should always be used [12]. In our opinion, such a procedure is necessary and the dressing should be maintained for 5-7 days.

Another unusual finding made during the second revision operation was to find significant remnants of the anterior crus of the stapes after the previous surgery, which caused an accretion of connective tissue and blocked free movement of the prosthesis. This made full hearing improvement impossible, especially in the low frequency range. This type of complication has not been described in the literature before. After removing the accretion and the remaining fragment of the stapes superstructure, it was possible to fully restore the mobility of the reconstructed middle ear conductive apparatus. The accretion of connective tissue on the stapes superstructure probably caused excessive insertion of the prosthesis into the vestibule, which led to balance disorders 3 months later. These complaints subsided completely immediately after 
revision, even before the dressing from the external auditory canal was removed.

The results obtained after the revision of the right ear were decisive, in the patient's opinion, in making a quick decision about surgery on the left ear and in obtaining closure of the air-bone gap in this ear using standard stapedotomy and the same type of prosthesis. Many authors draw attention to the good results obtained after revision surgery in otosclerosis by using a $\mathrm{CO}_{2}$ laser $[1,3,13]$. The limitation here is a thick stapes footplate.

The presented case provides possible reasons for failure of surgical treatment for otosclerosis, especially if there are high post-operative expectations. This reasoning has been confirmed by our evaluation of a large clinical material [14].

\section{Conclusions}

Revision operations in otosclerosis require a lot of experience due to many possible causes of failure. This is especially difficult when the first operation or operations were performed by another otosurgeon in another center. Identification of an air-bone gap, increasing tinnitus, and balance disorders are indications that the most experienced otosurgeon in the team should perform a reoperation. The most common reasons for failure are growing accretive lesions and immobilization of the implanted prosthesis.

\section{References:}

1. Lippy WH, Battista RA, Berenholz L, Schuring AG, Burkey JM. Twenty-year review of revision stapedectomy. Otol Neurotol, 2003; 24(4): 560-66.

2. Vincent R, Sperling NM, Oates J, Jindal M. Surgical findings and long-term hearing results in 3,050 stapedotomies for primary otosclerosis: a prospective study with the otology-neurotology database. Otol Neurotol, 2006; 27(8, Suppl 2): 25-47.

3. Vincent R, Rovers M, Zingade N, Oates J, Sperling N, Devèze A et al. Revision stapedotomy: operative findings and hearing results: a prospective study of 652 cases from the otology-neurotology database. Otol Neurotol, 2010; 31(6): 875-82.

4. Marchica CL, Saliba I. The relationship between stapes prosthesis length and rate of stapedectomy success. Clin Med Insights Ear Nose Throat, 2015; 8: 23-31.

5. Skrivan J, Cada Z, Kluh J, Boucek J, Profant O, Betka J. Revision operations after previous stapes surgery for persisting hearing loss. Bratisl Lek Listy, 2014; 115(7): 442-44

6. BIAP - Bureau International d'Audiophonologie, https://www. biap. org/en/component/content/article/65-recommendations/ ct-2-classification/5-biap-recommendation-021-bis

7. Puxeddu R, Ledda GP, Pelagatti CL, Salis G, Agus G, Puxeddu P. Revision stapes surgery for recurrent transmissional hearing loss after stapedectomy and stapedotomy for otosclerosis. Acta Otorhinolaryngol Ital Organo, 2005; 25(6): 347-52.
8. Bakhos D, Lescanne E, Charretier C, Robier A. A review of 89 revision stapes surgeries for otosclerosis. Eur Ann Otorhinolaryngol Head Neck, 2010; 127(5): 177-82.

9. Gros A, Vatovec J, Zargi M, Jenko K. Success rate in revision stapes surgery for otosclerosis. Otol Neurotol, 2005; 26(6): 1143-48.

10. Rosen S, Bergman M. The first one hundred cases of hearing improvement in stapes mobilization: a long term report. Laryngoscope, 1959; 69: 1060-65.

11. Salvinelli F, Casale M, Rinaldi V, Zini C. External auditory canal after stapedotomy: packing or not? Eur Arch Oto-RhinoLaryngol, 2007; 264(9): 1119-20.

12. Hirvonen TP. How we do it: stapes surgery without postoperative packing of the external auditory canal. Clin Otolaryngol, 2005; 30(2): 205-57.

13. Albers AE, Schönfeld U, Kandilakis K, Jovanovic S. $\mathrm{CO}_{2}$ laser revision stapedotomy. Laryngoscope, 2013; 123(6): 1519-26.

14. Skarżyński H, Młotkowska-Klimek P, Mrówka M, Skarżyński PH, Dziendziel B, Olszewski $Ł$ et al. Assessment of chosen problems of stapes surgery in otosclerosis: analysis of 14443 ears. 3rd Intenational Symp Otosclerosis Stapes Surg, 2014. 